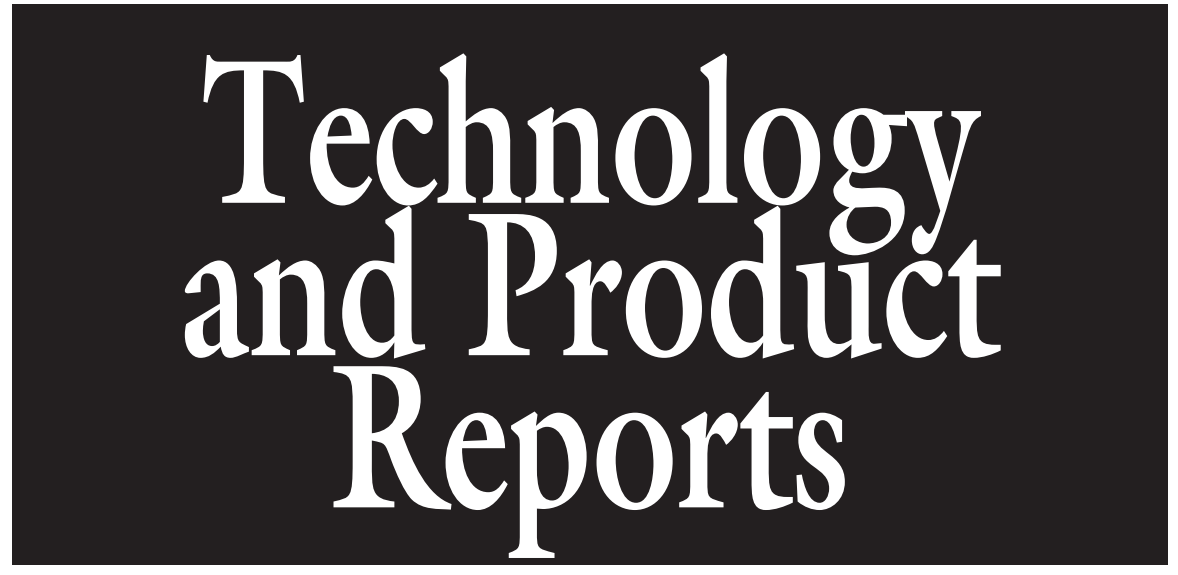

\section{A Topical Spray to Enhance Plant Resistance to Cold Injury and Mortality}

\author{
David A. Francko ${ }^{1,4}$, Kenneth G. Wilson ${ }^{2}$, Qingshun Q. Li $^{2}$, \\ and Maria A. Equiza ${ }^{2,3}$
}

ADDITIONAL INDEX wORDs. ornamentals, fruit crops, azalea, Begonia, Chamaedorea cataractarum, Citrus limon, Citrus sinensis, Citrus $\times$ tangerina, Fragaria ×ananassa, Lycopersicon esculentum, Musa basjoo, Musa acuminata, Rbododendron indica, Rosa chinensis minima, Sabal palmetto, Spatbiphyllum, Trachycarpus fortunei

Summary. A novel topical spray was developed to increase resistance to both cold damage and cold mortality in plant foliage, flowers, and fruits. In environmental chamber experiments, application of the spray to monocot and dicot foliage lowered the environmental temperatures associated with the first onset of cold injury and with cold mortality from 2.2 to $9.4^{\circ} \mathrm{F}$, compared with controls sprayed with tap water, over an effective temperature range (depending on species) of $\approx 0$ to $32^{\circ} \mathrm{F}$. The threshold temperature for flower mortality was lowered from 2.2 to $3.2{ }^{\circ} \mathrm{F}$ depending on species. Mature fruit suffered significantly less freeze damage when pretreated with the spray formulation. The spray is composed of ingredients that are non-toxic to plants, humans, and other animals. The patent-pending formulation has been commercialized under the trade name FreezePruf.

$\mathrm{T}$ he severity and duration of low temperatures that cause frost or freeze damage in plant tissues and organs are important abiotic

\footnotetext{
This work was supported by grants from the Ohio Plant Biotechnology Consortium, a Miami University Academic Challenge research grant, and the University of Alabama.

Under a licensing agreement between the University of Alabama and GroTech-sm, LLC, The Liquid Fence Company is sublicensed to produce and distribute FreezePruf and EcoLogic FreezePruf to homeowner and some professional markets. Additional sublicensing agreements are in process.

${ }^{1}$ Graduate School and Department of Biological Sciences, University of Alabama, Tuscaloosa, AL 35487

${ }^{2}$ Department of Botany, Miami University, Oxford, $\mathrm{OH} 45056$

${ }^{3}$ Current Address: Department of Renewable Resources, University of Alberta, Edmonton, AB, T6G 2E3, Canada.

${ }^{4}$ Corresponding author. E-mail: dfrancko@ua.edu.
}

factors limiting plant distribution and horticultural economics. Commercial growers often experience periodic frost/freeze damage to their crops even in areas where those species are normally well adapted. Many plant enthusiasts grow species at or even beyond their nominal U.S. Department of Agriculture (USDA) Plant Hardiness Zone ratings. Thus, there is great interest in developing methods to improve the cold tolerance characteristics of existing plant cultivars.
The variable ability of plant species to withstand frost or freeze conditions is genetically determined, and cold-tolerant plants, like their animal counterparts, exhibit two interrelated cold tolerance strategies: freeze tolerance and freeze avoidance (Lee, 1991). Freeze avoidance mechanisms use a variety of cryoprotectant molecules and other strategies that lower the intracellular freezing temperature (supercooling). For example, Francko and Wilson (2004) demonstrated that although cold-hardy palms (Palmae) exhibit a significant constitutive foliar coldresistance capability, enhanced cold tolerance (an additional 5 to $10{ }^{\circ} \mathrm{F}$ ) can rapidly be induced by exposure to above-freezing chilling temperatures. Freeze-point depression and thermocouple studies conducted on chinese windmill palm [Trachycarpus fortunei (Larcher et al., 1991)] and needle palm [Rhapidophyllum hystrix (Lokuge, 2006)] point to supercooling enhancement as a likely freeze avoidance mechanism involved in cold acclimation. However, supercooling alone is insufficient to protect plant tissues when temperatures drop low enough for ice crystals to form. Freeze tolerance mechanisms involve structural, anatomical, and biochemical adaptations to prevent or minimize damage to cells and tissues caused by ice formation. For example, addition of soluble silicates to soil media may enhance cold tolerance in crops via silica depositioninduced strengthening of cell walls (PQ Corporation, 2003). Larcher et al. (1991) suggested that low supercooling points noted in chinese windmill palm may have been due at least in part to cell walls strengthened with silica.

Thus, a topical spray designed to improve plant cold tolerance would ideally enhance both freeze avoidance and freeze tolerance mechanisms. To date, limited success has been reported in the development of foliar sprays designed to enhance supercooling in or on plant leaves and thus reduce frost, freeze damage, or both. These methods induce freezing point depression, inhibit ice-nucleating bacteria via

\begin{tabular}{llll}
\hline $\begin{array}{l}\text { Units } \\
\text { To convert U.S. to SI, } \\
\text { multiply by }\end{array}$ & U.S. unit & SI unit & $\begin{array}{l}\text { To convert SI to U.S., } \\
\text { multiply by }\end{array}$ \\
\hline 3.7854 & gal & $\mathrm{L}$ & 0.2642 \\
1 & $\mathrm{ppm}$ & $\mathrm{mg} \cdot \mathrm{L}^{-1}$ & 1 \\
0.9464 & $\mathrm{qt}$ & $\mathrm{L}$ & 1.0567 \\
$\left({ }^{\circ} \mathrm{F}-32\right) \div 1.8$ & ${ }^{\circ} \mathrm{F}$ & ${ }^{\circ} \mathrm{C}$ & $\left(1.8 \times{ }^{\circ} \mathrm{C}\right)+32$
\end{tabular}

Hortlechnology · February $201121(1)$ 
inorganic salts, or use organic polymers to create a vapor barrier at the leaf surface to provide modest frost and freeze protection (from $\approx 31$ to $28^{\circ} \mathrm{F}$ ) but have not been shown to enhance cold hardiness in frost-tolerant plants. Many existing technologies require the application of high concentrations of cryoprotectants dissolved in water [up to $10 \%$ by weight (Savignano and Hanafin, 1997)]. In the most successful patent in this genre that we are familiar with, Sekutowski et al. (2001) used a solution of hydrophobic materials to prevent ice crystal formation on leaf surfaces at temperatures at or below $\approx 21{ }^{\circ} \mathrm{F}$ and leaves were undamaged. In untreated leaves, water droplets froze and leaves were damaged at $29.3^{\circ} \mathrm{F}$. However, it is not clear whether this invention was persistent on leaf surfaces after precipitation events nor was an extensive range of plant species tested. Antidessicant spray manufacturers [e.g., Anti-Stress 2000 (Terra Tech, Eugene, OR) and Wilt-Pruf (Wilt-Pruf Products, Essex, CT)] claim that these agents may ameliorate freeze damage to plant foliage, but the mechanism appears to involve reduction of transpirational water loss rather than freeze damage per se (Francko, 2003).

The limited ability of existing spray products to protect frost-sensitive plants at temperatures much below freezing or to offer any significant freeze tolerance protection to coldtolerant, USDA Plant Hardiness Zone 7 to 9 a plants exposed to temperatures well below their typical tolerance limits $\left(0\right.$ and $20^{\circ} \mathrm{F}$, respectively) may be due in part to the mechanism through which the above cryoprotectants functionincreasing the solute content of extracellular water, intracellular cytoplasm, or both, and thus lowering the freezing point of these compartments. The very high solute concentrations required to significantly improve supercooling capacity can be toxic to cells and induce irreversible plasmolytic water loss from cell interiors, causing a detachment of the cell membrane from the cell wall and cell death.

We developed a novel foliar/ floral/fruit topical spray containing two multiple-benefit, mechanistically distinct cryoprotectants, a surfactant, a cell wall reinforcing compound, and an antidessicant, which was designed to reduce both the environmental temperature at which foliage, flowers, and fruits first become damaged by subfreezing cold and the environmental temperature at which plant structures are completely killed by cold. The formulation was designed to augment rather than replace a plant's native cold acclimation potential and to be effective over a broad range of species, both taxonomically and in terms of USDA Plant Hardiness Zone ratings.

Each of the five ingredients in our spray was chosen for its specific mode of action in hypothetically improving resistance to cold in plant tissues. In animals and insects, polyols like polyethylene glycol (PEG) appear to enhance cold tolerance through both freeze avoidance and freeze tolerance mechanisms. As solutes, they act colligatively via freezing point depression and non-colligatively by stabilizing cell membranes against freeze damage caused by ice crystals (Lee, 1991). Although no direct evidence for PEGinduced cold tolerance enhancement in plants has been reported, a plant tissue culture medium concentration of $\approx 2.5$ $\mathrm{mm}(4 \% \mathrm{w} / \mathrm{v})$ of high molecular weight PEG (PEG 8000, molecular weight 8 kDa; FisherBiotech, Fair Lawn, NJ) induces non-destructive cytorrhysis in arabidopsis (Arabidopsis thaliana), stabilizes cell membranes, and enhances production of the plant cryoprotectant proline (van der Weele et al., 2000; Verslues and Bray, 2004).

As a cell wall strengthening agent, AgSil 25, a proprietary solution of soluble potassium silicate (PQ Corporation, Valley Forge, PA) reduces crop stress due to drought, insect damage, and cold when applied as a foliar spray at a concentration of $\approx 10 \mathrm{~mm}$ soluble silicate (PQ Corporation, 2003). Glycerol at cellular concentrations of $\approx 5 \mathrm{~mm}$ is an important inducible low molecular weight cryoprotectant in animal systems but not in plants (Lee, 1991). As a non-plant-produced cryoprotectant, glycerol would not be expected to feedback-inhibit the production of natural plant cryoprotectants such as proline induced by cold acclimation. Most plants have waxy cuticles and a surfactant is required to aid assimilation of sprayed materials from the leaf surface into plant tissues. We employed a plantspecific silicone polyether copolymerbased surfactant (Silwet L-77; Setre Chemical Co., Memphis, TN) used with high efficacy $(0.1 \%$ to $1 \% \mathrm{v} / \mathrm{v})$ as an adjuvant to control plant diseases in many food crops (Tipping et al., 2003). As noted earlier, bicyclic oxazolidine-based antidessicant sprays are used in aqueous concentrations from $5 \%$ to $10 \%(\mathrm{v} / \mathrm{v})$ to reduce transpirational water loss from leaves during cold weather, transplantation stress for several weeks after application, or both. We used Wilt-Pruf as an antidessicant in our spray to reduce both winter water loss and wash-off of the cryoprotective compounds introduced into leaf tissues by our spray methodologies.

Each ingredient mentioned earlier is biodegradable and non-toxic to plants, humans, and other animals. PEG and glycerol are used extensively as components of human food and consumer products, and AgSil 25, Silwet L-77, and Wilt-Pruf are routinely used in row crop and fruit horticulture to improve crop yield and vigor.

\section{Materials and methods}

EXPERIMENTAL PLANTS USED. The efficacy of this topical spray was evaluated under controlled laboratory conditions using foliage, flowers, and fruits from herbaceous and woody plants common in the horticultural and agronomic trade, ranging from tropical plants with little or no resistance to freezing to more cold-tolerant species. Foliage plants included the common tropical house plant peace lily (Spathiphyllum spp.), the tropical banana species dwarf cavendish banana (Musa acuminata), the warm-temperate japanese fiber banana (Musa basjoo), the subtropical cat palm (Chamaedorea cataractarum), two warm-temperate palms [cabbage palm (Sabal palmetto) and chinese windmill palm], and an unnamed cultivar of sweet orange (Citrus sinensis). Foliage was sampled (fully expanded, intermediate age, healthy leaves cut at the petiole base immediately before use) from non-coldacclimated, potted ( 1 qt to $3 \mathrm{gal}$ ), greenhouse-grown specimens maintained under ambient natural light. In sweet orange, we also sampled newly expanded leaves in addition to older leaves. The greenhouse evaporative cooling system and supplemental heat maintained temperatures above $\approx 60$ ${ }^{\circ} \mathrm{F}$ in winter and below $\approx 95^{\circ} \mathrm{F}$ during summer. Plants were overhead irrigated twice weekly with water containing a dilute $(125 \mathrm{ppm})$ fertilizer solution $(20 \mathrm{~N}-8.7 \mathrm{P}-16.6 \mathrm{~K}$ in summer and $20 \mathrm{~N}-8.3 \mathrm{P}-14.9 \mathrm{~K}$ in winter; J.R. Peters, Allentown, PA). 
Laboratory experiments were also conducted on fully expanded flowers from meyer lemon (Citrus limon), miniature rose (Rosa chinensis minima), azalea (Rhododendron indicum 'Formosa'), and wax begonia (Begonia spp.). Azaleas were sampled from specimens in the first author's home landscape (late winter fertilization with a $10 \mathrm{~N}-4.4 \mathrm{P}-6.6 \mathrm{~K}$ slow-release formulation containing micronutrients; Swiss Farm Products, Las Vegas, NV). The other flowering plants were maintained in greenhouse pots as described earlier. Experiments on mature tomato (Solanum lycopersicum), strawberry (Fragaria $\times$ ananassa), and tangerine (Citrus $\times$ tangerina) fruits were conducted with grocery store produce from Florida (strawberry and tangerine) and California (tomato). Care was taken to purchase fruit from the same commercial supplier on the day it was delivered to the grocer, and experiments were commenced later that same day.

DETERMINATION OF SPRAY FORMULATION. The optimal concentration of each active agent to be included in a final spray formulation was determined by factorial design experiments conducted on plant foliage and flowers. The initial test solution contained concentrations of each agent cited in literature above to be optimally effective in eliciting their respective desired effects in plant tissues: $4 \%$ [w/ $\mathrm{v}(2.5 \mathrm{~mm})$ ] PEG 8000, $5 \mathrm{~mm}$ glycerol, $0.5 \%(\mathrm{v} / \mathrm{v})$ of concentrated AgSil 25 (10 $\mathrm{mm}$ final silicate concentration), $0.1 \%(\mathrm{v} / \mathrm{v})$ of concentrated Silwet L77 , and a 1:50 dilution ( $\mathrm{v} / \mathrm{v})$ of WiltPruf concentrate added to laboratory tap water. Tap water ( $\mathrm{pH} 7.9$ to 8.1 ) rather than distilled water was used to bring formulations to desired volume because, in practice, end users would be expected to use available tap water to dilute a commercial product. As formulated, the above test solution has a slightly basic $\mathrm{pH}(\approx 8.2)$ whether diluted with tap water or distilled water. In successive formulations, the concentration of a single ingredient was altered. Factorial design variations on the initial test solution concentrations, in addition to those listed earlier, included $0.8 \%, 1 \%, 2 \%$, and $8 \%$ PEG, 2 and $10 \mathrm{~mm}$ glycerol, $0.1 \%$ and $1 \% \mathrm{AgSil} 25,0.05 \%$ and $0.5 \%$ Silwet L-77, and $1: 20$ and $1: 100$ dilutions of Wilt-Pruf.

To test each solution, three excised leaves of sweet orange, cat palm, cabbage palm, chinese windmill palm, dwarf cavendish banana, japanese fiber banana, and peace lily and fullyexpanded flowers from meyer lemon and miniature rose were spray-treated with each formulation, subjected to environmental chamber cold assays, and visually scored for damage as described later. Because the colligative effects of cryoprotectants on freezing point depression are dependent on tissue water content, we also determined the water content in foliage of the above species. Freshly excised leaf samples were weighed to determine fresh weights, and leaves were then oven-dried overnight at $110^{\circ} \mathrm{C}$ to determine dry weights, permitting direct computation of foliar percent water content.

Cold treatment ASSAYs: LABORATORY. Plant material (freshly excised leaves; stem sections containing leaves, flowers, or both; individual mature fruit; or whole potted plants) was sprayed to runoff (upper and lower surfaces) with test formulation or tap water (controls) and allowed to air dry at room temperature for $\approx \mathrm{l} \mathrm{h}$. Excised leaves and stem sections were then placed in pre-misted (tap water), clear polyethylene bags with partially closed moisture seals for $24 \mathrm{~h}$ at room temperature to allow formulation to be incorporated into plant tissues without dessication. Intact whole plants and mature fruit were incubated at room temperature for $24 \mathrm{~h}$ without bagging.

After $24 \mathrm{~h}$ at room temperature, the plant material was placed in environmental chambers for $30 \mathrm{~min}$ to $9.5 \mathrm{~h}$, depending on the experiment to be performed, at various designated set point temperatures. For most short-term (30-min) incubations, excised plant parts were used rather than whole potted plants to reduce cooldown variability caused by the large thermal mass of pots and potting mix. Chambers (BOD 50A; Thermo Scientific Revco Products, Asheville, $\mathrm{NC})$ were temperature-calibrated before and during experiments with electronic thermometers. To ensure that chamber temperature readings accurately reflected plant tissue temperatures, additional temperature probes were placed in chambers immediately adjacent to plant samples. Opening the chamber to insert samples caused the air temperature within to rise, and it generally took $\approx 5$ to 15 min for temperatures to cool back down to the preset test temperature. Thus, tissue cooling rates in our experiments $\left(\approx 0.9\right.$ to $\left.1.8^{\circ} \mathrm{F} / \mathrm{min}\right)$ were faster than those typically seen in the field $\left(\approx \mathrm{l}\right.$ to $\left.2{ }^{\circ} \mathrm{F} / \mathrm{h}\right)$ during overnight freeze events. After timed incubation at the predetermined test temperature, chambers were turned off and leaves were allowed to warm gradually ( 10 to $30 \mathrm{~min}$ ) to near-ambient laboratory conditions. Excised leaves/stem sections were then placed in clear polyethylene bags with moisture seals and incubated for at least $24 \mathrm{~h}$ at room temperature before visual scoring for cold-induced necrotic tissue. Intact potted plants and mature fruit were generally incubated for $24 \mathrm{~h}$ before scoring, although peace lily exhibited maximal cold injury almost immediately upon removal from the chambers and tangerines and tomatoes required multiple days of incubation at room temperature before cold-induced damage could be scored.

Environmental chamber incubations were used to quantify two key temperature-dependent variables for foliage, flowers, and fruits from each species: 1) the temperature at which foliar/floral/fruit injury first became apparent and 2) the temperature that resulted in complete or near complete destruction of plant material. These temperature-dependent variables have already been benchmarked in field and laboratory work on untreated palms and other ornamentals (Dirr, 2002; Francko, 2000, 2003; Francko and Wilhoite, 2002; Francko and Wilson, 2004; Riffle, 1998).

To quantify spray formulation effectiveness in improving these two critical temperature benchmarks in each species, triplicate samples (spray-treated and control samples) of excised leaves and flowers or branch tips containing leaves and flowers were incubated at multiple temperatures, ranging from above the first injury temperature through the lethal temperature. In japanese fiber banana, replicate, l-qt potted plants were used in place of triplicate leaf samples. At each temperature, resultant damage to individual leaves, leaf segments, or flowers was visually scored using a percent areal viable leaf/flower tissue index method previously shown to provide rapid and accurate estimates of foliar damage in cold-stressed palms (Francko and Wilhoite, 2002). A mean value for percent areal foliar/floral tissue viability was then computed for 
treated and control samples for each species at each temperature, and in foliar samples, data were analyzed using linear regression plots of mean percent viable tissue as a function of decreasing temperatures. Regressions yielded statistically valid estimates for both the first damage temperature (the $100 \%$ live tissue intercept) and the lethal temperature (the $0 \%$ live tissue intercept) for foliage from each species.

Intact flowers displayed an "all or none" response to short-term cold exposure- little or no discernable damage was noted at a temperature only slightly warmer than the $100 \%$ damage temperature. Hence, floral mortality threshold temperatures for control and spray-treated flowers were determined by conducting successive incubations, each a few tenths of a degree $\left({ }^{\circ} \mathrm{F}\right)$ colder, until the warmest temperature that resulted in $100 \%$ floral mortality was determined for each species. At that critical temperature, the experiments were repeated and the pooled data (six flowers from each species) were subjected to statistical analyses.

To confirm the accuracy of excised leaf experiments, three 1 -qt chinese windmill palm and three 1 -qt cabbage palms were exposed to $30 \mathrm{~min}$ of cold treatment and three 1 -gal peace lily plants were exposed to $\mathrm{l} \mathrm{h}$ of cold treatments. Plants were incubated at set point temperatures that caused $\approx 90 \%$ foliar mortality in excised leaf regression experiments.

Analyses of mature fruit were conducted in a similar fashion using the commercially available version of the final spray formulation (Ecologic FreezePruf containing 2\% PEG; Liquid Fence Co., Broadheadsville, PA). Treated and control ripe tangerines (six each per experiment, replicated, and data pooled) were incubated for 2 to $6 \mathrm{~h}$ at temperatures $\left(16^{\circ} \mathrm{F}\right)$ known to cause significant freeze injury in the field (Chen and Carter, 1986; O'Connell, 1999). Fruit was scored as either viable (no discoloration or necrosis) or non-viable (necrosis, complete dessication, or both) after 11 to $16 \mathrm{~d}$ of post-cold-treatment incubation at room temperature. In analyses of tomato and strawberry fruits, a temperature of $25^{\circ} \mathrm{F}$ and incubation times of 2 or $3.5 \mathrm{~h}$ were used. Triplicate experiments using 3 to 12 fruit each were conducted and the results (viable vs. non-viable fruit remaining 96 and $48 \mathrm{~h}$ after cold treatment, respectively) were pooled for statistical analyses.

Phytotoxicity issues. As noted earlier, all spray treatment ingredients except glycerol are already in use in agriculture and plant issue culture with no toxicity issues. To determine whether our basic spray formulation could cause long-term phytotoxicity problems in non-cold-treated plants, l-qt greenhouse-cultured chinese windmill palm, cabbage palm, peace lily, and japanese fiber banana (six each) were treated with spray formulation containing $4 \%$ PEG, 5 mm glycerol, 0.5\% AgSil 25, $0.1 \%$ Silwet L-77, and a 1:50 dilution of Wilt-Pruf. In additional experiments (two plants of each species), the PEG content of the spray formulation was increased to $8 \%$ to simulate a 2 - to 4 fold over-application of the optimal formulation's major ionic component in each species. Finally, triplicate japanese fiber banana plants were doublesprayed over a 3 -h period with the $4 \%$ PEG version of the basic formulation. Plants were then maintained in the greenhouse under cultural conditions described earlier for 6 months. Nonspray-treated specimens served as controls. During the 6-month trials, foliar health in treated and untreated plants was periodically monitored.

Non-COLligative EFFeCTS OF SPRAY FORMULATION ON MEMBRANE STABILIZATION. To test the notion that our formulation improves plant response to internal ice formation via non-colligative stabilization of internal plant cell membranes, we conducted experiments on photosynthetic chloroplast membranes in sweet orange leaves using a rapid chlorophyll fluorescence analysis (Equiza and Francko, 2010).

The photosynthetic apparatus, in particular photosystem II (PSII), is highly sensitive to stress and can be damaged before any plasmalemma or tonoplast dysfunction becomes evident. Chlorophyll fluorescence responds to changes in PSII photochemistry and provides a sensitive tool to evaluate plant responses to different environmental stresses. One fluorescence parameter widely used as stress indicator is $\mathrm{Fv} / \mathrm{Fm}$, the maximum quantum efficiency of PSII, which represents the fraction of absorbed photons that are used for photochemistry for a darkadapted leaf. In a healthy leaf, Fv/Fm is $\approx 0.8$, and a decrease in $\mathrm{Fv} / \mathrm{Fm}$ is indicative of PSII stress, including field- evaluated frost/freeze damage (Equiza and Francko, 2010; Maxwell and Johnson, 2000; Percival and Henderson, 2003; Rizza et al., 2001).

Freezing tolerance/chlorophyll fluorescence assays in sweet orange leaves were evaluated using a pulsemodulated fluorometer (OS5-FL; Opti-Sciences, Hudson, NH). Control and spray formulation-treated leaves (three each) were dark-adapted for 45 min and $\mathrm{Fv} / \mathrm{Fm}$ values were measured immediately before and after ( 2 to $48 \mathrm{~h}$ ) freezing treatment (30 $\mathrm{min} ;-5.0,-6.5$, and $\left.-7.5^{\circ} \mathrm{C}\right)$. Fv $/$ Fm was calculated as $(\mathrm{Fm}-\mathrm{Fo}) / \mathrm{Fm}$, where Fo is the minimal fluorescence of a dark-adapted leaf and $\mathrm{Fm}$ is the maximal fluorescence of a dark-adapted leaf after a saturating flash (van Kooten and Snel, 1990). A second set of three was treated as mentioned earlier and cold-incubated at the same temperatures for use in parallel visual damage estimations.

\section{Results and discussion}

OPTIMAL SPRAY FORMULATION. Factorial design laboratory cold treatment experiments demonstrated that the initial spray formulation of $4 \%$ PEG, 5 mm glycerol, 0.5\% (v/v) AgSil $25,0.1 \%$ Silwet-L77 (v/v), and a 1:50 $(\mathrm{v} / \mathrm{v})$ dilution of Wilt-Pruf concentrate produced optimal effects in highwater-content tropical plants such as peace lily and bananas (86\% and $91 \%$ water, respectively, based on fresh weight vs. dry weight determinations). Within the range of concentrations tested, changes in glycerol, AgSil 25, Silwet L-77, or Wilt-Pruf content produced statistically similar results to the initial spray formulation $[P>$ 0.05 ; single factor analysis of variance (ANOVA)]. However, the optimal concentration of PEG, as the predominant solute molecule by weight in the formulation, differed among the seven test species and was linearly correlated $(y=$ $5.233 x+65.8 ; r=0.7329 ; P<0.01)$ with the mean foliar water content of plant leaves and flowers. For example, in chinese windmill palm (68\% water) and cabbage palm (73\% water) leaves exposed for $30 \mathrm{~min}$ to temperatures causing complete to near complete foliar mortality in controls $\left(5.2^{\circ} \mathrm{F}\right)$, spray formulation containing PEG concentrations ranging from $0.8 \%$ to $4 \%$ each increased the mean foliar survival percentage above controls by statistically similar amounts (Fig. 1), but 2\% PEG consistently produced the optimal effect 
and higher and lower PEG concentrations produced more statistically variable results (Fig. 1). In sweet orange leaves and meyer lemon flowers, the optimal PEG content was 1\%. Hence, in succeeding experiments described here, we used three variations of the optimal spray formulation, each varying only in PEG concentration: a $4 \%$ PEG concentration for high-watercontent tropical foliage, a 1\% PEG content version for citrus foliage and all flowers, and 2\% PEG for all other plants and plant parts.

LABORATORY LINEAR REGRESSION MODELING ON TARGET SPECIES. Linear regression analyses of percent live foliar tissue remaining in control vs. optimal spray formulation-treated leaves as a function of decreasing temperature demonstrated that the formulation improved both the initial foliar damage threshold and the foliar mortality threshold in all seven species examined. In peace lily, for example (Fig. 2, top), control leaves began to show damage at $\approx 29.7^{\circ} \mathrm{F}$, damage increased linearly with further drops in temperature, and leaves were completely destroyed at $26.1{ }^{\circ} \mathrm{F}$. Formulation-treated leaves (4\% PEG) remained undamaged even at $20.8^{\circ} \mathrm{F}$ but suffered complete mortality at $18.9^{\circ} \mathrm{F}$. Thus, in 30 -min cold incubations, the spray formulation lowered the initial damage and foliar mortality thresholds by 9.4 and $7.2^{\circ} \mathrm{F}$, respectively. Peace lily leaves (treated and control) were frozen at temperatures below $28^{\circ} \mathrm{F}$, but only formulationtreated leaves remained viable when

\section{Chinese windmill palm}
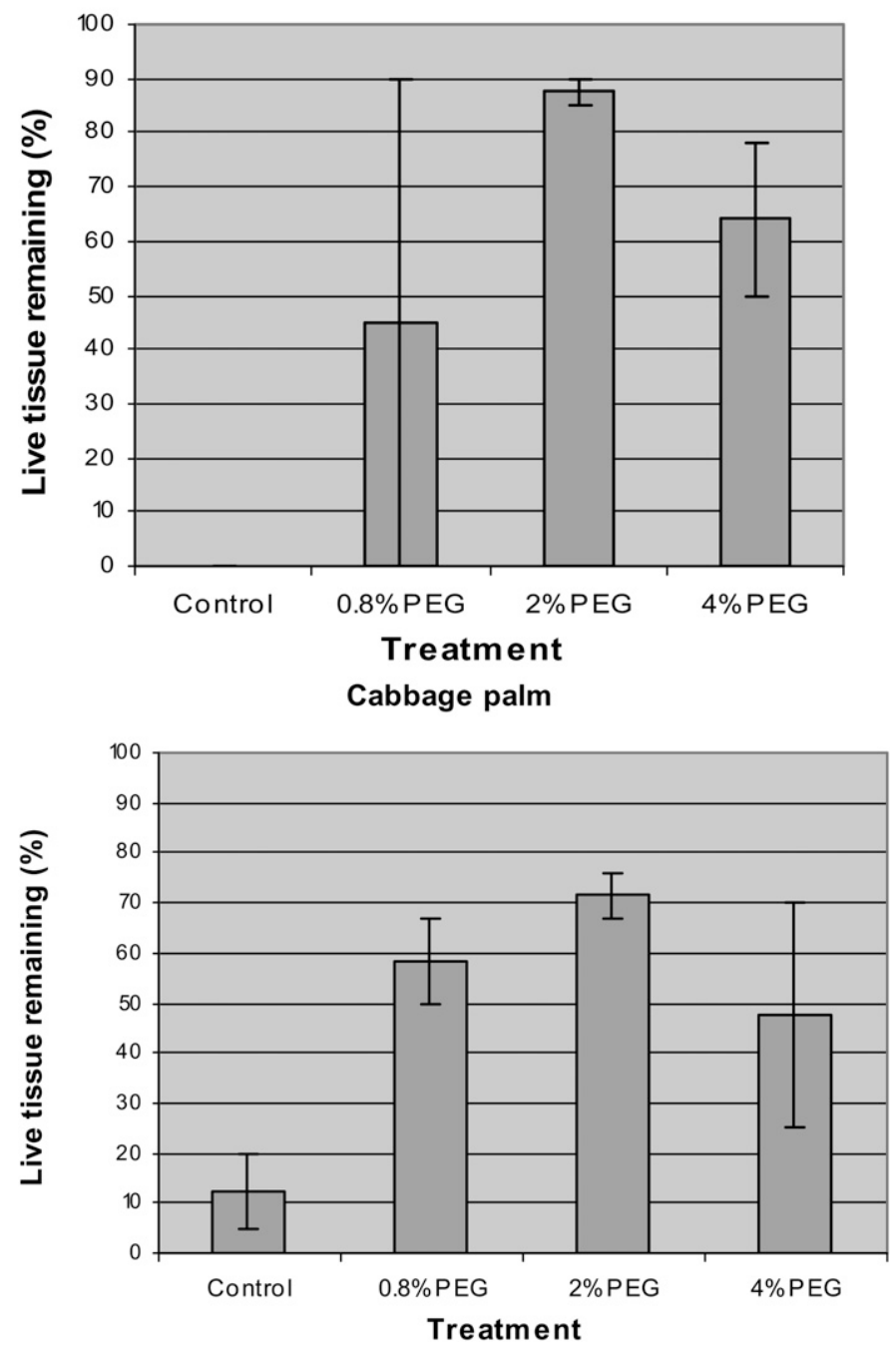

Fig. 1. Percent live leaf tissue remaining in control chinese windmill palm and cabbage palm foliage vs. leaves treated with spray formulation containing $0.8 \%, 2 \%$, or $4 \%$ polyethylene glycol and subjected to 30 -min incubations at $5.2{ }^{\circ} \mathrm{F}\left(-14.89^{\circ} \mathrm{C}\right)$. Data shown as mean \pm SD (three leaves per species/temperature).

thawed. These data supported the view that the spray formulation improved both freeze avoidance and freeze tolerance performance in peace lily foliage. Similarly, in japanese fiber banana (Fig. 2, lower), both control and formulation-treated leaves (4\% PEG) experienced linearly increasing damage as incubation temperatures decreased, but the formulation shifted the $100 \%$ live tissue intercept by $7.7^{\circ} \mathrm{F}$ and the $0 \%$ live tissue intercept by $6.1^{\circ} \mathrm{F}$. As with peace lily, formulation-treated banana foliage remained viable even when frozen and then thawed.

Initial foliar damage and foliar mortality temperatures for all seven target species, with and without spray formulation treatment, are shown in Table 1. Linear regression lines in both control and treated variants as a function of decreasing temperature were statistically significant in all species $(P<$ $0.05 ; r$ values ranging from 0.717 to $0.996)$. In all species, spray formulation treatment improved leaf response to increasingly cold temperatures, as compared with controls, across the range of temperatures tested $(P<$ 0.05 ; paired sample $t$ test and Wilcoxin signed ranks test). These species have widely varying cold tolerance characteristics, suggesting that the spray formulation was effective over a very broad temperature range, from just below freezing to $\approx 0{ }^{\circ} \mathrm{F}$. The threshold temperature for initial foliar damage in spray formulation-treated leaves was lowered by a minimum of $2.3{ }^{\circ} \mathrm{F}$ in sweet orange ( $1 \%$ PEG) to a maximum of $9.4^{\circ} \mathrm{F}$ in peace lily ( $\left.4 \% \mathrm{PEG}\right)$. The foliar mortality threshold temperature was lowered by a minimum of $2.2^{\circ} \mathrm{F}$ in sweet orange ( $1 \%$ PEG) to a maximum of $7.2^{\circ} \mathrm{F}$ in peace lily. The $\approx 2$ to $9^{\circ} \mathrm{F}$ range of improvement over controls indicated that the spray formulation was capable of adding the equivalent of $\approx 0.25$ to nearly 1.0 USDA Plant Hardiness Zone to the foliar hardiness rating of test species under laboratory conditions.

Experiments using potted chinese windmill palm, cabbage palm, and peace lily suggested that the above results on excised leaves were a good surrogate for whole plants. In each species, the foliar damage in intact potted control and formulation-treated plants fell within the $95 \%$ confidence interval estimate of the regression line determined for that species/treatment regime using excised leaves. For example, 
control foliage in 1-gal peace lily specimens (Fig. 3) was heavily damaged at $29^{\circ} \mathrm{F}$. In contrast, formulation-treated peace lilies were virtually undamaged at $23^{\circ} \mathrm{F}$. Thus, the temperature-dependent damage to intact potted peace lilies closely paralleled the 29.7 and $23.5^{\circ} \mathrm{F}$ critical temperature for first foliar
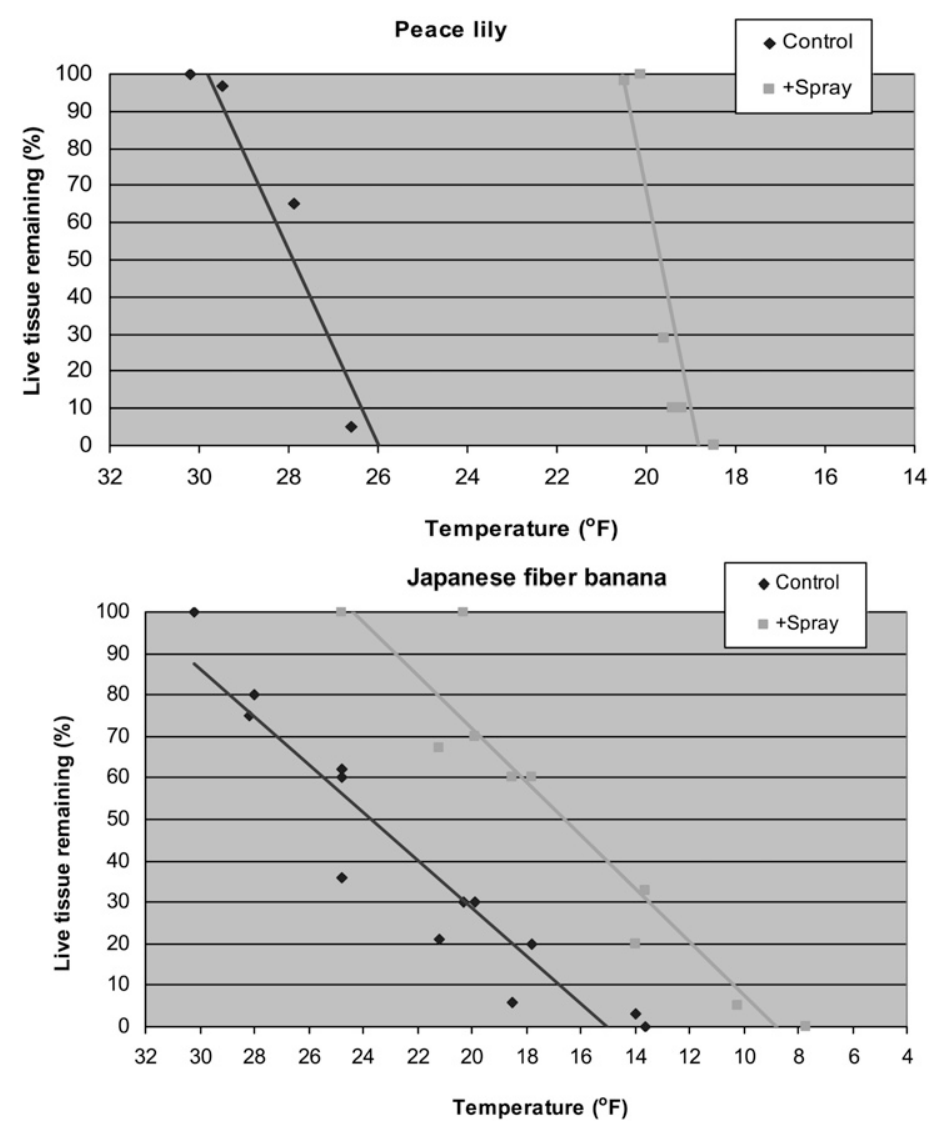

Fig. 2. Linear regression plots showing percent live leaf tissue remaining $24 \mathrm{~h}$ after 30 -min exposure to various test temperatures with and without $4 \%$ polyethylene glycol-containing spray formulation treatment in peace lily (three leaves at each temperature) and japanese fiber banana (two potted plants at each temperature). All regression lines were significant at the $0.05 \%$ level. Regression equation $r$ values are shown in Table $1 ;\left({ }^{\circ} \mathrm{F}-32\right) \div 1.8={ }^{\circ} \mathrm{C}$.

damage in regression analyses of control and formulation-treated excised leaves, respectively (Table 1 ).

The spray formulation ( $1 \%$ PEG) also significantly improved $(P<0.05$; paired sample $t$ test and Wilcoxin signed ranks test) the mortality threshold of intact, fully opened flowers from four different species compared with controls (Table 2). Individual species' improvements ranged from $2.2^{\circ} \mathrm{F}$ in miniature rose flowers to $3.2{ }^{\circ} \mathrm{F}$ in begonia, but all flowers exhibited a statistically similar mean improvement in the foliar mortality threshold when treated with the spray formulation $\left[2.6 \pm 0.5(\mathrm{SD})^{\circ} \mathrm{F} ; \mathrm{P}>0.05\right.$; single factor ANOVA].

A commercially available version of the spray formulation, EcoLogic FreezePruf containing 2\% PEG, effectively reduced freeze damage in mature fruit from several commercially important crops. In multiple experiments on ripe tomatoes exposed to $25^{\circ} \mathrm{F}$ temperatures for 2 to $3.5 \mathrm{~h}$, post-freeze fruit necrosis (cracked skins, necrotic lesions, and rotting; Fig. 4) was reduced from more than $50 \%$ in controls to $\approx 5 \%$ in FreezePruf-treated fruit $(P<0.01$; single factor ANOVA; Table 3$)$. Similarly, nearly $70 \%$ of control strawberries assayed $48 \mathrm{~h}$ after exposure to $25^{\circ} \mathrm{F}$ for $2 \mathrm{~h}$ were necrotic, rotting, and heavily leaking fluids when assayed $48 \mathrm{~h}$ after cold treatment, but $83 \%$ of FreezePruftreated strawberries remained in viable, salable condition $(P<0.05$; single factor ANOVA). FreezePruf-treated strawberry viability was statistically similar $(P>0.05$; ANOVA) to noncold-treated control fruit incubated at

Table 1. Linear regression-derived initial foliar damage temperatures (100\% live tissue intercept) and foliar mortality threshold temperatures ( $0 \%$ live tissue intercept) in plant species treated with spray formulation [ $4 \%$ polyethylene glycol (PEG) in peace lily and bananas, $2 \%$ PEG in palms, and $1 \%$ PEG in sweet orange] vs. controls after 30-min exposures to various environmental chamber temperatures. The net improvement between spray-treated vs. control foliage is also shown.

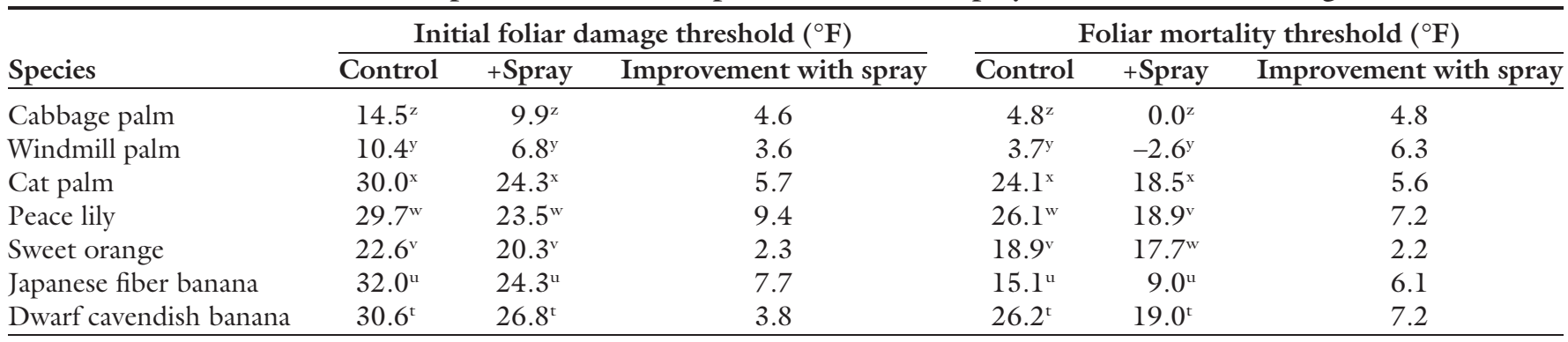

${ }^{2}$ Regression $r$ values: control $=0.991(P<0.05) ;+$ spray $=0.791(P<0.05)$

${ }^{\mathrm{y}}$ Regession $r$ values: control $=0.952(P<0.05),+$ spray $=0.843(P<0.05)$

'Regression $r$ values: control $=0.934(P<0.05)$, + +spray $=0.855(P<0.05)$.

"Regression $r$ values: control $=0.954(P<0.05),+$ spray $=0.904(P<0.05)$.

vRegression $r$ values: control $=0.815(P<0.05),+$ spray $=0.717(P<0.05)$

"Regression $r$ values: control $=0.939(P<0.05),+$ spray $=0.950(P<0.05)$.

${ }^{t}$ Regression $r$ values: control $=0.962(P<0.05),+$ spray $=0.996(P<0.05)$. 


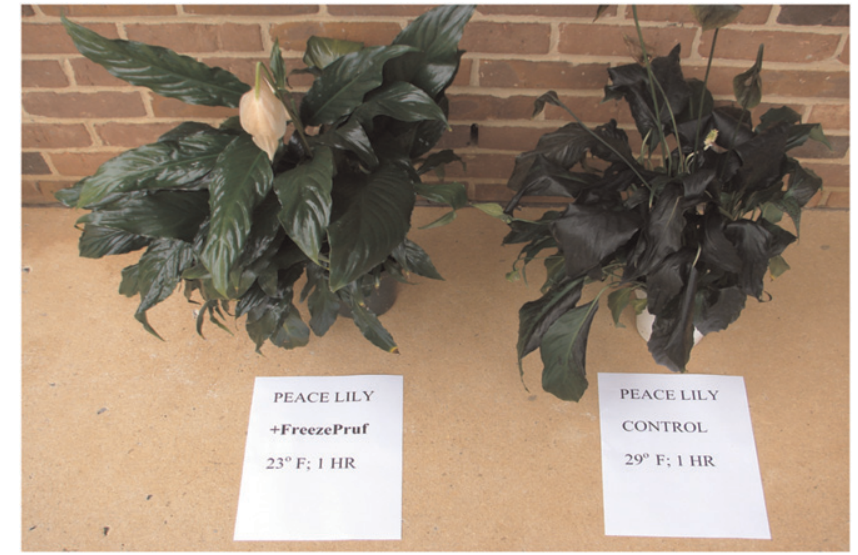

Fig. 3. Potted 1-gal $(3.8 \mathrm{~L})$ peace lily with and without spray formulation treatment (4\% polyethylene glycol) exposed to 23 or $29^{\circ} \mathrm{F}\left(-5.0\right.$ or $\left.-1.7^{\circ} \mathrm{C}\right)$, respectively, for $1 \mathrm{~h}$. Photo was taken $4 \mathrm{~h}$ after removal from the environmental chamber.

Table 2. Floral mortality threshold temperatures in control flowers and flowers treated with $1 \%$ polyethylene glycol-containing spray formulation and subjected to 60-min (azalea) or 30-min (balance of species) environmental chamber cold exposure (six flowers per species/temperature). The net improvement with spray treatment vs. corresponding control is also shown.

\begin{tabular}{lccc}
\hline Species & \multicolumn{2}{c}{ Floral mortality threshold $\left({ }^{\circ} \mathbf{F}\right)$} & $\begin{array}{c}\text { Improvement } \\
\text { with spray }\left({ }^{\circ} \mathbf{F}\right)\end{array}$ \\
\cline { 2 - 4 } Control & + Spray & $2.3^{\mathrm{z}}$ \\
Meyer lemon & 30.0 & 27.7 & $2.2^{\mathrm{z}}$ \\
Miniature rose & 23.9 & 21.7 & $2.5^{\mathrm{z}}$ \\
Azalea & 31.5 & 29.0 & $3.2^{\mathrm{z}}$ \\
Begonia & 29.0 & 25.8 & \\
\hline
\end{tabular}

${ }^{2}$ Significant improvement from controls at $P<0.05$ via paired sample $t$ test and Wilcoxin signed ranks test.

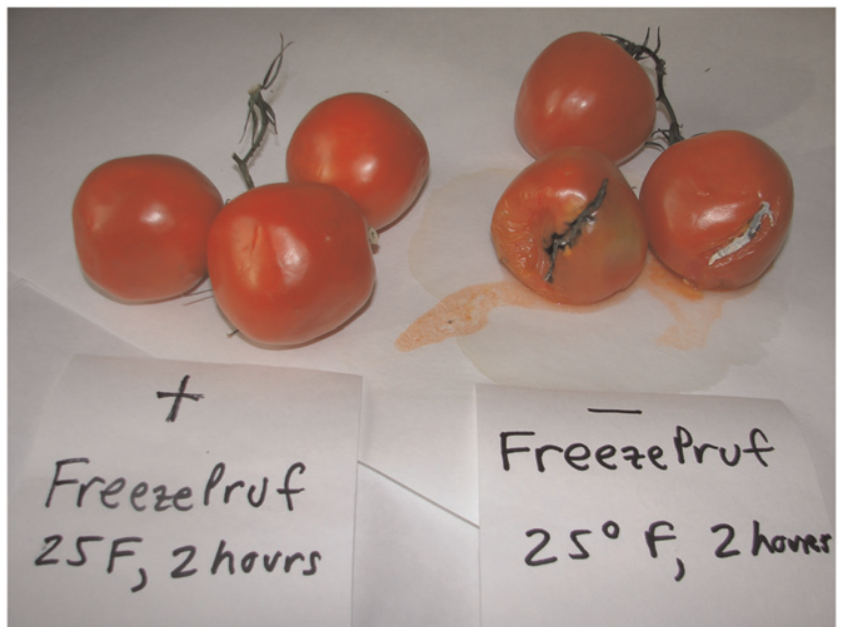

Fig. 4. Tomatoes treated with a commercial version of the spray formulation (Ecologic FreezePruf containing 2\% polyethylene glycol; Liquid Fence Co., Broadheadsville, PA] and controls (left and right, respectively) after incubation in environmental chambers for $2 \mathrm{~h}$ at $25^{\circ} \mathrm{F}\left(-3.9^{\circ} \mathrm{C}\right)$. Photo was taken $96 \mathrm{~h}$ after removal from chamber.

room temperature for the same $48 \mathrm{~h}$. In strawberry trials, both control and FreezePruf-treated fruit were solidly frozen by the 2 -h cold treatment. The surface layers of tomatoes were similarly hard to the touch, especially after 3.5 -h cold treatment. This suggests that the improvement in post-cold-treatment fruit viability with FreezePruf may have been due to enhanced freeze tolerance and not simply an improvement in supercooling capacity.

The protective effect of FreezePruf was not confined to small (strawberry) or thin-skinned (tomato) fruit. In Florida tangerines subjected to 2.5 to $6 \mathrm{~h}$ of cold treatment at $16^{\circ} \mathrm{F}$, regression analyses (Fig. 5) showed that damage to control fruit began occurring at $\approx 2 \mathrm{~h}$ and increased linearly $(y=$ $-20.61 x+138.7 ; r=0.871 ; P<0.02)$ with time, with $\approx 80 \%$ of the fruit judged non-viable (necrosis/rotting, complete dehydration of juice sacks; Fig. 6 ) after $6 \mathrm{~h}$ of cold treatment. In FreezePruf-treated tangerines, damage started occurring at $\approx 2.5 \mathrm{~h}$ and increased linearly with time $(y=$ $-12.28 x+128.96 ; r=0.923 ; P<$ $0.01)$. Though the slopes of these two regression lines were statistically similar $(0.10<P<0.25)$, FreezePruf shifted the entire response curve "upward" so that treated fruit exhibited enhanced viability at each time interval in the 4.5-h range of incubation times tested $(P<0.05$; Wilcoxin signed ranks test and paired sample $t$ test). After $6 \mathrm{~h}$ at $16{ }^{\circ} \mathrm{F}, \approx 60 \%$ of FreezePruf-treated tangerines remained viable compared with $\approx 20 \%$ of controls. About twothirds of both control and FreezePruftreated tangerines were solidly frozen or nearly so within $3.5 \mathrm{~h}$ at $16^{\circ} \mathrm{F}$ and all were frozen by $6 \mathrm{~h}$, suggesting that, like strawberry and tomato above, improvement in fruit viability noted with FreezePruf was likely due to enhanced freeze tolerance in juice sacks vs. an improvement in freeze avoidance behavior.

Phytotoxicity issues. In all the above experiments on laboratory spray formulation or FreezePruf efficacy, we could not identify a single instance of treatment-related damage to foliage, flowers, or fruits. The results on 6month posttreatment greenhouse trials on non-cold-treated potted japanese fiber banana, peace lily, cabbage palm, and chinese windmill palm sprayed with the initial 4\% PEG formulation similarly revealed no changes in growth patterns or damage to foliage. Finally, no foliar damage was noted in plants treated with $8 \%$ PEG spray formulation to simulate a 2 -fold (peace lily and bananas) or 4-fold (cabbage palm and windmill palm) over-application of the major ionic component of the optimal formulation or in japanese fiber banana specimens treated with a double application of the optimal 4\% PEG formulation. 
Table 3. Viability percentages in control strawberry and tomato fruit vs. fruit treated with Ecologic FreezePruf (Liquid Fence Co., Broadheadsville, PA) containing $2 \%$ polyethylene glycol in fruit exposed to $25^{\circ} \mathrm{F}\left(-3.9^{\circ} \mathrm{C}\right)$ for 2 or $3.5 \mathrm{~h}$.

\begin{tabular}{lcc}
\hline & Control viable (\%) & +FreezePruf viable (\%) \\
\hline Tomato & & \\
Expt. 1 $(3)^{\mathrm{z}}$ & 33 & 100 \\
Expt. 2 $(4)^{\mathrm{z}}$ & 50 & 100 \\
Expt. 3 $(6)^{\mathrm{y}}$ & 50 & 83 \\
Mean \pm SD & $44.3 \pm 9.8$ & $94.3 \pm 9.8^{\mathrm{x}}$ \\
& & \\
Strawberry & 17 & 100 \\
Expt. 1 $(6)^{\mathrm{z}}$ & 20 & 83 \\
Expt. 2 $(5)^{\mathrm{z}}$ & 58 & $83.3 \pm 16.5^{\mathrm{w}}$ \\
Expt. 3 $(12)^{\mathrm{z}}$ & $31.7 \pm 22.9$ & \\
Mean \pm SD & &
\end{tabular}

The number of control and treated fruit assayed in each experiment is shown in parentheses.

${ }^{\mathrm{z}} 2$-h incubation.

y 3.5 -h incubation.

Significant difference from control at $P<0.01$ via single-factor analysis of variance (ANOVA).

wignificant difference from control at $P<0.05$ via single-factor ANOVA.

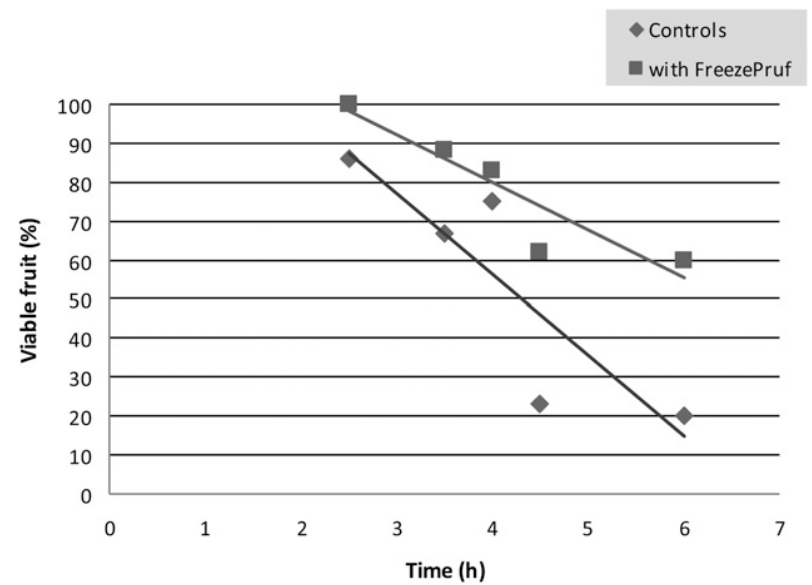

Fig. 5. Linear regression plots of percent viable tangerine fruit remaining as a function of laboratory cold treatment time at $16^{\circ} \mathrm{F}\left(-8.9^{\circ} \mathrm{C}\right)$ for control fruit and fruit treated with EcoLogic FreezePruf (Liquid Fence Co., Broadheadsville, PA) containing $2 \%$ polyethylene glycol. Damage (necrosis/rotting/complete dehydration of juice sacks) was scored 11 - to 16 -d posttreatment ( 12 fruit/cold incubation time period).

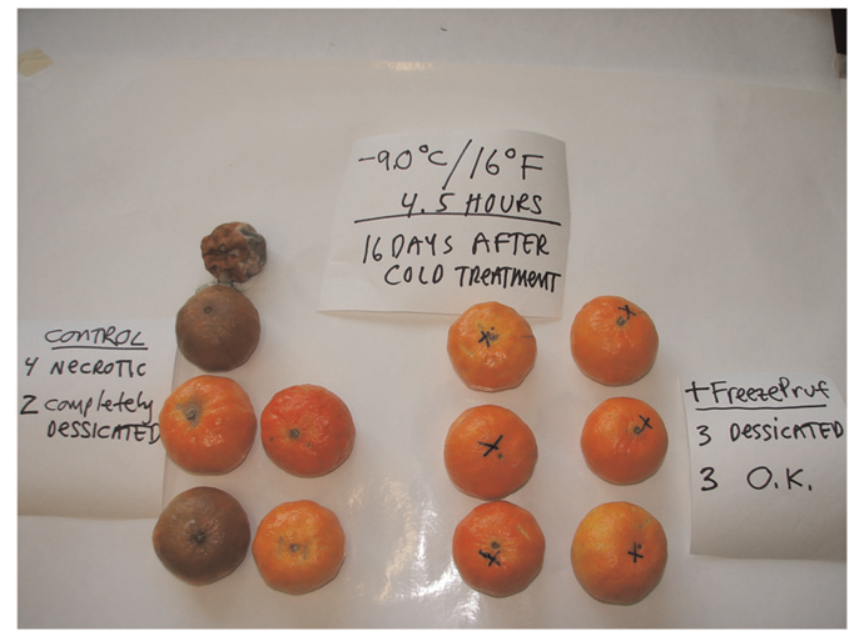

Fig. 6. Visual evidence of cold damage in tangerine for control fruit and fruit treated with Ecologic FreezePruf (Liquid Fence Company, Broadheadsville, PA) containing $2 \%$ polyethylene glycol following incubation at $16^{\circ} \mathrm{F}\left(-8.9^{\circ} \mathrm{C}\right)$ for $4.5 \mathrm{~h}$.
Non-COLligative EFFECTS OF SPRAY FORMULATION ON MEMBRANE STABILIZATION. Fv/Fm data demonstrated that laboratory spray formulation ( $1 \%$ PEG) treatment had a positive protective effect on photosynthetic membrane protection in both older and newly expanded sweet orange leaves (Fig. 7). The effective temperature range for this protective effect, as measured by Fv/Fm assays, closely resembled visual damage/mortality curves determined for a parallel set of sweet orange leaves (three at each temperature) cold-treated in tandem with leaves used for $\mathrm{Fv} / \mathrm{Fm}$ experiments (Table 4). At $-5.0{ }^{\circ} \mathrm{C}$, which approximates to the 30 -min critical temperature for first foliar injury in control leaves of sweet orange (Table 1), both control and spray formulation-treated old and newly expanded leaves displayed unchanging Fv/Fm curves between time zero (after spraying and right before cold treatment) and 2, 24, and $48 \mathrm{~h}$ posttreatment, implying that photosystem membranes had remained undamaged. Similarly, no visible leaf damage was apparent in old or new leaves at that temperature. At $-6.5^{\circ} \mathrm{C}$, all three old control leaves and one of the three new control leaves exhibited pronounced Fv/Fm degradation with time and visually scored control leaves exhibited the same pattern of damage. No spray formulationtreated leaves exhibited a decreased $\mathrm{Fv} / \mathrm{Fm}$ or visual damage at $-6.5^{\circ} \mathrm{F}$. At $-7.5{ }^{\circ} \mathrm{C}, 100 \%$ of old and new control leaves and $100 \%$ of the formulation-treated new leaves were visually destroyed, while two of three formulation-treated old leaves remained viable. The Fv/Fm data for new control and formulation-treated leaves were identical to visual scoring: all exhibited complete photosystem degradation. Among older leaves, there were small differences between $\mathrm{Fv} / \mathrm{Fm}$ trends and visual scoring: all three formulationtreated leaves retained stable $\mathrm{Fv} / \mathrm{Fm}$ values, indicative of functional photosystems, even though one of the leaves appeared to be non-viable based on visual evidence.

ANOVA of repeated Fv/Fm measurements showed that the differences between spray formulation-treated and control leaves were statistically significant at both -6.5 and $-7.5{ }^{\circ} \mathrm{C}(P<$ $0.001)$. Fv/Fm measurements suggested that the formulation induced a 1.0 to $2.0^{\circ} \mathrm{C}$ decrease in the lethal 

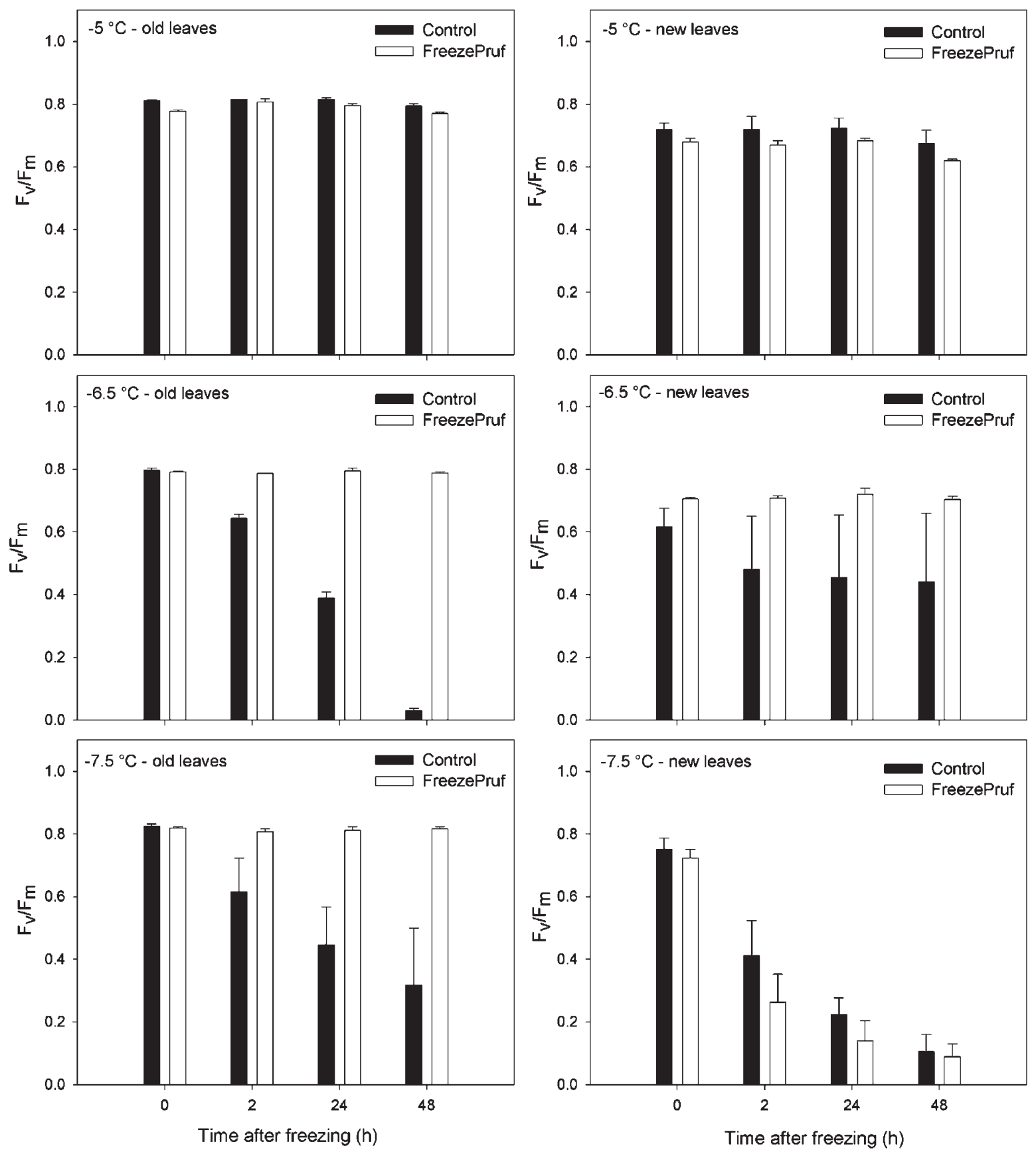

Fig. 7. Maximum quantum efficiency of photosystem II $(\mathrm{Fv} / \mathrm{Fm})$ curves for individual cold-treated $\left[-5.0,-6.5\right.$, and $-7.5{ }^{\circ} \mathrm{C}$ $\left(23.00,20.30\right.$, and $\left.\left.18.50^{\circ} \mathrm{F}\right)\right]$ older and newly expanded sweet orange leaves (three leaves each temperature) as a function of time after treatment with and without spray formulation treatment ( $1 \%$ polyethylene glycol). Error bars denote the SE of the mean.

Table 4. Viable leaf tissue remaining in control older and newly expanded sweet orange leaves vs. leaves treated with spray formulation containing $1 \%$ polyethylene glycol after cold exposure at various temperatures for $30 \mathrm{~min}$ (three leaves each temperature/treatment).

\begin{tabular}{|c|c|c|c|c|}
\hline \multirow[b]{3}{*}{ Temperature $\left({ }^{\circ} \mathbf{C}\right)$} & \multicolumn{4}{|c|}{ Viable leaf tissue $[$ mean $\pm \mathrm{sD}(\%)]$} \\
\hline & \multicolumn{2}{|c|}{ Old leaves } & \multicolumn{2}{|c|}{ Newly expanded leaves } \\
\hline & Control & + Spray & Control & + Spray \\
\hline-5.0 & $100 \pm 0$ & $100 \pm 0$ & $100 \pm 0$ & $100 \pm 0$ \\
\hline-6.5 & $0 \pm 0$ & $100 \pm 0^{\mathrm{z}}$ & $67 \pm 57$ & $100 \pm 0$ \\
\hline-7.5 & $0 \pm 0$ & $67 \pm 57^{\mathrm{z}}$ & $0 \pm 0$ & $0 \pm 0$ \\
\hline
\end{tabular}

${ }^{2}$ Spray treatment means significantly different from controls at $P<0.05$ via paired sample $t$ test and Wilcoxin signed ranks test. 
temperature, similar to the value of $1.2{ }^{\circ} \mathrm{C}$ determined by visual scoring (Tables 1 and 4).

\section{Conclusion}

These data show that the laboratory spray formulation and the commercial version of this spray (FreezePruf) decreased both the first damage temperature and the mortality temperature of a wide variety of monocot and dicot foliage, flowers, and fruits. Beneficial effects were noted within hours of application. The formulation appeared to enhance both freeze avoidance and freeze tolerance in plants via colligative and non-colligative mechanisms. The magnitude of cold tolerance improvement $\left(2.2\right.$ to $9.4^{\circ} \mathrm{F}$ under laboratory conditions) suggests that the spray formulation could add the equivalent of $\approx 0.25$ to almost 1.0 USDA Plant Hardiness Zone to the cold hardiness rating of plants tested. No short- or long-term phytotoxicity issues were noted, and the components of the laboratory spray formulation and FreezePruf are all either human food ingredients or used in the human food production chain. Based on effectiveness data and its non-toxic, ecofriendly formulation, the evidence suggests that the spray formulation could offer significant benefits to users in the residential and commercial sectors.

\section{Literature cited}

Chen, C.S. and R.D. Carter. 1986. Temperature changes in citrus fruit at subfreezing temperatures. Proc. Florida State Hort. Soc. 99:128-131.

Dirr, M.A. 2002. Dirr's trees and shrubs for warm climates. An illustrated encyclopedia. Timber Press, Portland, OR.
Equiza, M.A. and D.A. Francko. 2010. Assessment of freezing injury in palm species by chlorophyll fluorescence. HortScience 45:845-848.

Francko, D.A. 2000. Effect of microclimate variation on cultivation of coldhardy palms in southwestern Ohio. Palms 44:37-46.

Francko, D.A. 2003. Palms won't grow here and other myths: Warm-climate plants for cooler regions. Timber Press, Portland, OR.

Francko, D.A. and K. Wilson. 2004. A new way to test for palm cold hardiness. Hardy Palm Intl. 58:26-29.

Francko, D.A. and S. Wilhoite. 2002. Cold-hardy palms in southwestern Ohio: Winter damage, mortality and recovery. Palms 46:5-13.

Larcher, W., U. Meindle, E. Ralser, and M. Ishikawa. 1991. Persistent supercooling and silica deposition in cell walls of palm leaves. J. Plant Physiol. 139:146154.

Lee, R.E. 1991. Principles of insect low temperature tolerance, p. 17-46. In: R.E. Lee and D.L. Denlinger (eds.). Insects at low temperature. Chapman and Hall, New York.

Lokuge, M. 2006. Tissue culture, genetic transformation and cold tolerance mechanisms in cold-hardy palms. Miami Univ., Oxford, OH, PhD Diss.

Maxwell, K. and G.N. Johnson. 2000. Chlorophyll fluorescence: A practical guide. J. Expt. Bot. 51:659-668.

O’Connell, N. 1999. Post-freeze citrus culture-1998-1999. Citrus Notes Jan. 1999. Univ. California Coop. Ext., Tulare County, CA.

Percival, G.C. and A. Henderson. 2003. An assessment of the freezing tolerance of urban trees using chlorophyll fluores- cence. J. Hort. Sci. Biotechnol. 78:254260.

PQ Corporation. 2003. AgSil potassium silicate: Soluble silicate for agriculture. Rpt. 24. PQ Corporation, Valley Forge, PA.

Riffle, R.E. 1998. The tropical look. An encyclopedia of dramatic landscape plants. Timber Press, Portland, OR.

Rizza, F., D. Pagani, A.M. Stanca, and L. Cattivelli. 2001. Use of chlorophyll fluorescence to evaluate the cold acclimation and freezing tolerance of winter and spring oats. Plant Breeding 120:389-396.

Savignano, J.P. and J.W. Hanafin. 1997. Process for preventing frost formation on plants. U.S. Patent 5653054, U.S. Patent and Trademark Office, Washington, D.C.

Sekutowski, D.G., G.J. Puterka, D.M. Glenn, and M. Wisniewski. 2001. Method for enhancing supercooling of plants to provide frost protection. U.S. Patent 6235683. U.S. Patent and Trademark Office, Washington, D.C.

Tipping, C., V. Bikoba, G.J. Chandler, and E.J. Mitcham. 2003. Efficacy of Silwet L-77 against several arthropod pests of common table grape. J. Econ. Entomol. 96:246-250.

van der Weele, C.M., W.G. Spollen, R.E. Sharp, and T.I. Baskin. 2000. Growth of Arabidopsis thaliana seedlings under water deficit studied by control of water potential in nutrient-agar media. J. Expt. Bot. 51:1555-1562.

van Kooten, O. and J.F.H. Snel. 1990. The use of chlorophyll fluorescence nomenclature in plant stress physiology. Photosyn. Res. 25:147-150.

Verslues, P.E. and E.A. Bray. 2004. LWRI and LKR2 are required for osmoregulation and osmotic adjustment in Arabidopsis. Plant Physiol. 136:28312842. 